\title{
PESAN MORAL PERNIKAHAN PADA FILM WEDDING AGREEMENT (ANALISIS SEMIOTIKA ROLAND BARTHES)
}

\author{
Nita Khairani Amanda ${ }^{1}$, Yayu Sriwartini $^{1}$ \\ ${ }^{1}$ Program Studi Ilmu Komunikasi, Universitas Nasional \\ email:khaerani20@gmail.com,yayu_sriwartini@yahoo.com \\ Korespondensi : yayu_sriwartini@yahoo.com
}

\begin{abstract}
Film mass media was chosen as the most effective media in conveying messages, because film can be used as a learning medium through messages that are represented in scenes or narratives of stories. Lessons can be taken in the form of moral messages, or one of them is about the moral messages of marriage contained in the Film Wedding Agreement. This film discusses the side of married life being mocked, with a marriage agreement that says the couple will divorce after one year of marriage. This type of research is qualitative with the nature of descriptive research. This study uses Roland Barthes's semiotic analysis method, in this analysis there are three core things that are the focus, namely the Denotative, Connotative, and Mythical meaning used by researchers as a guide to see the depiction of marriage moral messages drawn in each film scene. The data obtained in this study is sourced from the Iflix application that shows Film Wedding Agreement and is combined with books that discuss the film and the moral message of marriage. The results showed that the representation of the moral message of marriage that appears in the film Wedding Agreement, is in the form of fulfilling the rights and obligations of a husband and wife. Like, the obligation to maintain mutual relations, love one another, respect each other, and meet the needs of the household. In this film the director wants to highlight the side of how a couple to maintain their relationship by combining the cultural values of Indonesian marriage and the values of Islamic religious marriage that can be used as a lesson for filmmakers of the Wedding Agreement. In addition, this film not only has a moral message of marriage, but there are other moral messages related to everyday life.
\end{abstract}

Keywords: semiotics, film, marriage moral message, weeding agreement,message

\begin{abstract}
Abstrak
Media massa film dipilih sebagai media yang paling efektif dalam menyampaikan pesan, karena film dapat digunakan sebagai media pembelajaran melalui pesan yang direpresentasikan ke dalam adegan atau narasi cerita. Pelajaran yang dapat diambil berupa pesan moral, atau salah satunya tentang pesan moral pernikahan yang terkandung dalam Film Wedding Agreement. Film ini membahas sisi kehidupan pernikahan yang dipermainkan, dengan adanya perjanjian pernikahan yang menyebutkan pasangan akan bercerai usai satu tahun pernikahan. Jenis penelitian yang digunakan adalah kualitatif dengan sifat penelitian deskriptif. Penelitian ini mengunakan metode analisis semiotika Roland Barthes, dalam
\end{abstract}


analisis ini terdapat tiga hal inti yang menjadi fokus yaitu makna Denotatif, Konotatif, dan Mitos yang digunakan peneliti sebagai panduan untuk melihat pengambaran terkait pesan moral pernikahan yang tergambar disetiap adegan film. Data yang didapatkan dalam penelitian ini bersumber dari aplikasi Iflix yang menayangkan Film Wedding Agreement dan digabungkan dengan buku-buku yang membahas mengenai film dan pesan moral pernikahan. Hasil penelitian yang menunjukan bahwa representasi pesan moral pernikahan yang tampil dalam film Wedding Agreement, adalah berupa pemenuhan hak dan kewajiban seorang suami istri. Seperti, kewajiban saling menjaga hubungan, mencintai satu sama lain, menghormati satu sama lain, dan memenuhi kebutuhan rumah tangga. Dalam film ini sutradara ingin menonjolkan sisi bagaimana cara seorang pasangan untuk menjaga hubungan mereka dengan menggabungkan nilai budaya pernikahan indonesia dan nilai-nilai pernikahan agama islam yang dapat dijadikan sebuah pembelajaran bagi penonton film Wedding Agreement. Selain itu, film ini tidak hanya memiliki pesan moral pernikahan, tetapi terdapat pesan moral lainnya yang berhubungan dengan kehidupan sehari-hari.

Kata kunci : semiotika, film, pesan moral pernikahan, weeding agreement, pesan

\section{PENDAHULUAN}

Pengaruh yang diberikan film sangatlah besar bagi kehidupan seseorang, karena film memiliki sebuah rencana khusus untuk mempengaruhi jiwa, pemikiran, gaya hidup, tingkah laku, bahkan sampai perkataan seseorang yang menontonnya. Film dapat dijadikan sebagai media pembelajaran tentang kehidupan, merubah pemikiran seseorang serta tingkah lakunya, karena adanya pesan moral yang terdapat di dalam sebuah film. Hal tersebut dapat berhubungan dengan nilai kehidupan, nilai agama, nilai budaya, atau nilai sosial lainnya dan lebih dikenal dengan nilai moral.

Perkembangan film di Indonesia saat ini sedang mengalami kemajuan yang cukup pesat. Tak sedikit film produksi Indonesia yang sudah meraih beberapa prestasi baik di dalam atau di luar negeri. Dari banyaknya genre film yang ada, misalnya genre komedi, drama, horor, dan fiksi. Penonton Indonesia lebih menyukai film dengan bergenre drama yang membahas tentang kehidupan sehari-hari untuk ditonton. Dengan alasan karena adanya kesamaan dengan realitas sosial yang terjadi dalam kehidupan nyata, membuat film bergenre drama banyak dipilih untuk ditonton oleh masyarakat. Hal tersebut dibuktikan dengan hasil suvey yang dilakukan IDN Times pada tahun 2019 tentang minta penonton terhadap film Indonesia.

Dari beberapa genre film yang sering tayang didunia perfilman Indonesia, genre drama menduduki posisi kedua dalam suara sebanyak 30,7\%. Selain itu, survei ini juga membahas tentang alasan mengapa masyarakat memilih menonton film Indonesia. Dalam survei ini dijabarkan terdapat dua alasan yang memiliki nilai tertinggi tentang menjadikan penonton menyukai film Indonesia. Pada posisi pertama, alasan terkuatnya yaitu relatable dengan kehidupan nyata dengan angka $37,2 \%$ dan diposisi kedua karena adanya pesan moral dengan angka 27,1 \%. (IDN Times, Infografis Minat Penonton Terhadap Film Indonesia, 2019, (www.idntimes.com). Dari hasil survei tersebut dapat menjadi penggambaran alasan mengapa orang menyukai menonton film, yaitu pertama karena adanya kesamaan 
dengan realita yang terjadi dan kedua adanya pesan moral yang disampaikan dalam film.

Di Indonesia sendiri pada tahun 2019 terdapat beberapa film yang tayang dengan pembahasan tentang realitas kehidupan yang menjadi topik utama. Seperti, film Keluarga Cemara, Dua Garis Biru, dan Bebas sebagai salah satu film yang membahas kehidupan sehari-hari. Tetapi dari banyaknya realitas yang dibahas, terdapat salah satu film yang memiliki cerita yang berbeda dari lainnya dengan membahas kehidupan pernikahan yang dipermainkan dengan menggabungkan unsur agama dalam film.

Film tersebut berjudul Wedding Agreement, film ini bergenre drama yang rilis pada tahun 2019 dan disutradarai oleh Archie Hekagery. Kisah dalam film ini diangkat berdasarkan novel yang telebih dahulu poluper pada aplikasi Wattpad. Novel tersebut memiliki judul yang sama dengan film dan ditulis oleh Eria Chuzaimiah alias Mia Chuz. Film ini berdurasi 90 menit dan peran utama dalam film ini yaitu Abyantara Wicaksana, Btari Hapsari, dan Sarah.

Film Wedding Agreement pada hari pertama penayangannya meraih 70 ribu penonton (www.liputan6.com), dan selama 35 hari penayangan jumlah yang menonton film ini sebanyak 893.136 di bioskop (Instargram Starvision, Jumlah Penonton Wedding Agreement. Diakses pada 27 Desember 2019, www.instagram.com. Dalam film Wedding Agreement memiliki banyak pelajaran tentang pernikahan dan memberikan gambaran para penonton tentang bagaimana kehidupan pernikahan yang akan dialami setiap manusia. Melalui film ini memberikan gambaran tentang seorang istri yang berusaha menjalankan perannya sebagai seorang istri yang baik, walaupun keduanya menikah karena dijodohkan.

Topik pembahasan mengenai kehidupan pernikahan merupakan sesuatu menarik untuk dibahas, dan dapat dijadikan sebuah bekal bagi para penonton. Karena keputusan untuk menikah merupakan tindakan yang sangat besar dalam kehidupan manusia, karena pernikahan akan menimbulkan sebuah ikatan yang terjadi diantara kedua pasangan.

Menurut salah satu psikolog Dr. Rose yang dikutip dari situs okezone.com menyebutkan bahwa sebuah pernikahan ideal yaitu jika sepasang kekasih memiliki komitmen untuk membangun rumah tangga menuju masa depan yang baik (Pernikahan Ideal Menurut Psikolog, diakses pada 02 Januari 2020). Serta, menjalankan pernikahan tidak hanya sebatas membutuhkan cinta dan kasih sayang antar pasangan. Melainkan setiap pasangan juga harus siap untuk membangun sebuah komitmen seumur hidup dengan pasangan dalam menjalani semua keadaan yang akan terjadi kedepan bersama-sama.

Dimulai dari mengenal dan memahami diri sendiri, memahami arti dari pernikahan itu sendiri karena adanya komitmen yang dibangun tentang kesiapan pasangan menerima kosekuensi dari pernikahan itu sendiri. Perlu diingat juga setiap pasangan harus menerima apapun yang sudah menjadi pilihannya, salah satunya kemungkinan untuk memiliki anak.

Tetapi, film Wedding Agreement membahas kehidupan pernikahan dari sudut pandang yang berbeda, Kompasiana mengatakan film ini membahas tentang bagaimana sisi pernikahan yang dipermainkan. Bukan untuk melanggengkan 
pernikahan, namun ada suatu niatan dengan jangka waktu tertentu untuk bisa menghancurkan pernikahan itu sendiri. (Kompasiana, Memaknai Ketulusan Cinta Sebuah Pernikahan dalam Wedding Agreement. Diakses pada 13 Januari 2019 pukul 23.29, (www.kompasiana.com).

Padahal dalam Undang-Undang No.1 Tahun 1974 telah dijelaskan bahwa: "Perkawinan ialah ikatan lahir bathin antara seorang pria dan seorang wanita sebagai suami istri dengan tujuan membentuk keluarga (rumah tangga) yang bahagia dan kekal berdasarkan Ketuhanan Yang Maha Esa." Maka, setiap pasangan wajib menghindari pernikahan mereka dari sebuah perceraian, walaupun dengan beberapa alasan perceraian itu diperbolehkan terjadi.

Selain itu jika melihat fenomena pernikahan yang terjadi di Indonesia dengan angka perceraian selalu meningkat setiap tahunnya, hal tersebut dapat dijadikan sebuah gambaran. Jika kehidupan pernikahan bukanlah hal yang mudah dan dapat dilalui begitu saja. Keputusan untuk menikah bukanlah suatu hal yang mudah untuk diputuskan, banyak pertimbangan yang diperlukan oleh pasangan sebelum memutuskannya. Karena tidak sedikit juga orang dewasa yang mengalami perceraian, dan banyak faktor yang melatarbelakangi terjadinya perceraian tersebut.

Mengutip dari Detik.com yang menyampaikan sepanjang tahun 2018 terdapat 419.268 pasangan yang bercerai. Dari jumlah itu insiatif perceraian paling banyak dari pihak perempuan sebanyak 307.778, sedangkan pihak laki-laki sebanyak 111.490 orang. (www.detik.com)

Selain itu, banyak sekali dampak yang akan ditimbulkan jika perceraian, salah satunya tentang pandang negatif yang diberikan oleh masyarakat. Maka dari itu moral pernikahan sangatlah penting ketahui oleh setiap pasangan, karena menikah itu bukanlah hanya hubungan antar pasangan saja tetapi ada hubungan dengan agama, keluarga dan lingkungan sekitar.

Maka dari itu dari beberapa fenomena yang telah dijelaskan, alasan peneliti memilih film Wedding Agreement untuk dijadikan objek penelitian karena film ini dapat menjadi gambaran tentang pernikahan bukanlah suatu yang dapat dipermainkan atau sebatas dengan surat perjanjian saja. Tetapi terdapat beberapa kewajiban yang harus dilakukan atau dipenuhi oleh pasangan setelah menikah.

Lewat film ini penonton dapat mengambil sebuah pelajaran tentang bagaimana menjalani pernikahan, hal apa yang dapat dilakukan dan tidak dapat dilakukan dalam pernikahan, serta beberapa hal hukum tentang pernikahan. Peneliti akan mengkaji pesan moral pernikahan yang terkandung dalam film Wedding Agreement, melalui tanda dan simbol yang ada dalam disetiap adegan-adegan atau dialog dalam film.

Dari latar belakang yang sudah dipaparkan, peneliti telah menentukan rumusan masalah yakni "Bagaimana penggambaran tentang pesan moral pernikahan yang terkandung dalam film Wedding Agreement ?". Serta, tujuan penelitian ini adalah untuk mengetahui penggambaran pesan moral pernikahan yang ingin disampaikan oleh pembuat film.. 


\section{TINJAUN PUSTAKA \\ Moral}

Moral, berasal dari kata Latin mores yang artinya tata cara dalam kehidupan, adat istiadat, kebiasaan. Moral pada dasarnya merupakan rangkaian nilai tentang berbagai macam perilaku yang harus dipatuhi (Mohammad Ali dan Mohammad Asrori, 2012). Kata "moral" selalu mengacu pada baik buruknya manusia sebagai manusia (Hiro Tugiman, 2012).

Moral sebenarnya memuat dua segi yang berbeda, yakni segi batiniah dan segi lahiriah. Dengan kata lain, moral rupanya hanya dapat diukur secara tepat apabila kedua seginya diperhatikan untuk menilai sikap batin maupun perbuatan lahir dibutuhkan suatu alat, yakni ukuran moral. Ukuran tersebut ada di dalam hati dan ukuran yang digunakan oleh seseorang ketika menilai diri kita. Kalau dalam hati kita ada ukuran subjektif dan ukuran orang lain yang lebih objektif. Aspek keutamaan dari moral dapat dilihat dari sikap kerendahan hati, kepercayaan pada orang lain, keterbukaan, kebijaksanaan, ketekunan kerja, kejujuran, keadilan, keberanian, penuh harap, penuh kasih, dan sebagainya (Al. Purwa Hadiwardoyo, 1994).

Menurut K.Bertens ( 2011) nilai moral tidak terpisahkan dari nilai-nilai jenis lainnya. Setiap nilai dapat memperoleh suatu "bobot moral", bila diikutsertakan dalam tingkah laku moral. Walaupun nilai moral biasanya menumpang pada nilainilai lain, namun ia tampak sebagai suatu nilai baru, bahkan sebagai nilai yang paling tinggi.

\section{Pernikahan}

Pernikahan merupakan peristiwa paling sakral dialami oleh setiap manusia, nikah/perkawinan artinya suatu akad yang menghalalkan pergaulan antara seorang laki-laki dan seorang perempuan yang bukan muhrim dan menimbulkan hak dan kewajiban antara keduanya (Asbar Tantu, 2013). Perkawinan mempunyai maksud agar suami istri dapat membentuk keluarga yang kekal bahagia, sesuai pula dengan hak azasi manusia, maka perkawinan harus disetujui oleh kedua belah pihak yang melangsungkan perkawinan tersebut, tanpa ada unsur paksaan dari pihak manapun (Armansyah Matondang, 2014)

Dalam agama Islam telah mensyari'atkan yakni pernikahan untuk membentuk mahligai keluarga sebagai sarana untuk meraih kebahagiaan hidup. Islam juga mengajarkan pernikahan merupakan suatu peristiwa yang patut disambut dengan rasa syukur dan gembira. Islam telah memberikan konsep yang jelas tentang tatacara ataupun proses sebuah pernikahan yang berlandaskan Al-Qur`an dan AsSunnah yang shahih (Ahmad Atabik dan Khoridatul Mudhiia, 2014).

\section{Syarat dan Rukun Nikah}

Akad pernikahan dikatakan sah apabila akad tersebut dilaksanakan dengan syarat- syarat dan rukun-rukun yang lengkap sesuai dengan ketentuan agama (Ahmad Atabik dan Khoridatul Mudhiia, 2014). Di Indonesia, para ahli hukum Islam sepakat bahwa akad nikah itu baru terjadi setelah dipenuhinya rukun-rukun dan syarat-syarat nikah, yaitu: 
1. Calon pengantin itu kedua-duanya sudah dewasa dan berakal (akil balig).

2. Harus ada wali bagi calon pengantin perempuan.

3. Harus ada mahar (mas kawin) dari calon pengantin laki-laki yang diberikan setelah resmi menjadi suami istri kepada istrinya.

4. Harus dihadiri sekurang-kurangnya 2 (dua) orang saksi yang adil dan lakilaki Islam merdeka.

5. Harus ada upacara ijab qabul, ijab ialah penawaran dari pihak calon istri atau walinya atau wakilnya dan qabul penerimaan oleh calon suami dengan menyebutkan besarnya mahar (mas kawin) yang diberikan.

6. Sebagai tanda bahwa telah resmi terjadinya akad nikah (pernikahan) maka hendaknya diadakan walimah (pesta pernikahan).

\section{Prinsip Hukum Perkawinan}

Prinsip-prinsip hukum perkawinan yang bersumber dari Alquran dan Alhadits, yang kemudian dituangkan dalam garis-garis hukum melalui UndangUndang Nomor 1 Tahun 1974 tentang perkawinan dan Kompelasi Hukum Islam Tahun 1991 mengandung 7 (tujuh) asas atau kaidah hukum, yang sebagai berikut (Asbar Tantu, 2014) :

1. Asas membentuk keluarga yang bahagia dan kekal. Suami dan istri perlu saling membantu dan melengkapi agar masing-masing dapat mengembangkan kepribadiannya untuk mencapai kesejahteraan spiritual dan material.

2. Asas keabsahan perkawinan didasarkan pada hukum agama dan kepercayaan bagi pihak yang melaksanakan perkawinan, dan harus dicatat oleh petugas yang berwenang.

3. Asas monogami terbuka. Artinya, jika suami tidak mampu berlaku adil terhadap hak-hak istri bila lebih dari seorang maka cukup seorang istri saja.

4. Asas calon suami dan calon istri telah matang jiwa raganya dapat melangsungkan perkawinan, agar mewujudkan tujuan perkawinan secara baik dan mendapat keturunan yang baik dan sehat, sehingga tidak berpikir kepada perceraian.

5. Asas mempersulit terjadinya perceraian.

6. Asas keseimbangan hak dan kewajiban antara suami dan istri, baik dalam kehidupan rumah tangga maupun dalam pergaulan masyarakat. Oleh karena itu, segala sesuatu dalam keluarga dapat dimusyawarahkan dan diputuskan bersama oleh suami istri.

7. Asas pencatatan perkawinan. Pencatatan perkawinan mempermudah mengetahui manusia yang sudah menikah atau melakukan ikatan perkawinan.

Selain itu, (Hadiwardoyo, 1994) menjelaskan sifat Pokok Perkawinan ada empat. Setia dengan satu pasangan, tak terceraikan karena perceraian resmi akan menyangkut banyak pihak. Heteroseksualitas, memiliki ketertarikan dengan lawan jenis. Dan yang terakhir, terbuka dengan adanya anak. 


\section{Persiapan Pernikahan}

1. Persiapan konseptual. Persiapan konseptual merupakan persiapan terhadap konsep pernikahan dan rumah tangga yang akan dijalani. Sebelum menikah sudah selayaknya calon pasangan mempelajari ilmu pernikahan dan rumah tangga islami agar rumah tangga yang baru di bina akan berjalan sesuai dengan yang diharapkan.

2. Persiapan mental Cara sederhana mempersiapkan mental adalah dengan meyakinkan diri bahwa pernikahan itu adalah ibadah yang harus dikerjakan dengan niat ikhlas, sehingga tidak mudah goyah hanya karena sedikit ketakutan yang tidak beralasan.

3. Persiapan materi Bagi seseorang yang hendak menikah khususnya laki-laki, sudah selayaknya memikirkan bagaimana cara ia menafkahi keluarganya setelah menikah. Nafkah merupakan salah satu kewajiban yang harus ditunaikan oleh seorang suami dan akan berdosa jika mengabaikan persoalan ini. (Hafiza Idayu, 2018).

\section{Hak dan Kewajiban Suami Istri Menurut UU Perkawinan Tahun 1974}

Pada Undang-Undang Perkawinan tahun 1974 mengatur hak dan kewajiban dari seorang suami istri, yaitu :

1. Hak dan kedudukan istri adalah seimbang dengan hak dan kedudukan suami dalam kehidupan rumah tangga dan pergaulan hidup bersama dalam masyarakat.

2. Suami istri wajib saling saling cinta mencintai, hormat menghormati, setia dan memberi bantuan lahir bathin yang satu kepada yang lain.

3. Suami wajib melindungi istrinya dan memberikan segala sesuatu keperluan hidup berumah tangga sesuai dengan kemampuannya.

4. Istri wajib mengatur urusan rumah-tangga sebaik-baiknya.

Tugas pokok suami-istri yaitu keduanya wajib untuk saling membahagiakan, membangun keluarga yang harmonis, bersedia memiliki anak dan mendidiknya. Selain itu terdapat beberapa hal yang perlu diperhatikan dalam pernikahan yaitu poligami, perceraian, perselingkuhan, dan penguguran.

\section{Hak dan Kewajiban Suami Istri Menurut Perspektif Islam}

Dikuti dari laman pm.unida.gontor.ac.id hak dan keawajiban suami istri dalam perspektif Islam ialah sebagai berikut:

- Hak Istri

1. Hak mengenai harta yaitu mahar atau mas kawin dan nafkah.

2. Hak mendapat perlakuan baik dari suami. Allah berfirman:

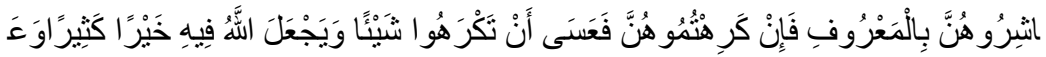

Artinya: "Dan bergaullah dengan mereka (istri) secara patut. Kemudian bila kamu tidak menyukai mereka, (maka bersabarlah) karena mungkin kamu tidak menyukai sesuatu, padahal Allah menjadikan padanya kebaikan yang banyak." (An Nisa:19). 
- Hak Suami

1. Ketaatan istri kepada suami dalam melaksanakan urusan rumah tangga termasuk di dalamnya memelihara dan mendidik anak, selama suami menjalankan ketentuan-ketentuan Allah SWT yang berhubungan dengan kehidupan suami istri.

- Kewajiban istri

1. Hormat dan patuh pada suami dalam batas-batas yang ditentukan oleh norma dan susila.

2. Mengatur dan mengurus rumah tangga, menjaga keselamatan dan mewujudkan kesejahteraan keluarga.

- Kewajiban suami

1. Memelihara, memimpin dan membimbing keluarga lahir dan batin, serta menjaga dan bertanggungjawab atas keselamatan dan kesejahteraannya.

2. Memberi nafkah sesuai kemampuan serta mengusahakan keperluan keluarga terutama sandang, pangan dan papan.

\section{Moral Pernikahan}

Dari beberapa penjelasan diatas dapat disederhanakan bahwa, moral pernikahan merupakan baik/buruk perilaku manusia dalam pernikahan yang ditinjau dari bagaimana pasangan menjalani kehidupan pernikahan mereka. Dikarenakan pernikahan merupakan peristiwa sakral yang terjadi dalam kehidupan manusia yang menghalalkan hubungan antar seorang laki-laki dan seorang perempuan, lalu menimbulkan hak dan kewajiban diantara keduanya.

Selain itu, pasangan perlu dibekali oleh beberapa persiapan yang perlu dimilikinya, seperti kesiapan mental menghadapi sebuah hubungan yang lebih kekal dan telah diatur oleh hukum yang kuat. Hal tersebut dikarenakan hubungan berpacaran dengan hubungan pernikahan memiliki perbedaan, sehingga pasangan perlu mengetahui ilmu tentang pernikahan atau ilmu tentang rumah tangga. Semua itu dilakukan untuk memahami hal apa saja yang diperbolehkan dan tidak diperbolehkan dalam menjalani kehidupan pernikahan.

Dari beberapa penjelasan di atas, untuk membantu peneliti dalam menganalisis pesan moral pernikahan yang tergambar dalam film Wedding Agreement peneliti membaginya kedalam beberapa kategori, yaitu :

a. Kesiapan mental pasangan dalam menjalani kehidupan pernikahan. Pada kategori ini diharapkan terdapat adegan film yang memberikan gambaran terkait kesiapan pasangan dalam menjalani kehidupan pernikahan.

b. Menjalani kewajiban pernikahan untuk saling mencintai dan membahagiakan, setia, membangun keluarga yang harmonis, menghormati satu sama lain, dan memberi bantuan lahir bathin kepada pasangan. Pada kategori ini diharapkan terdapat adegan film yang memberikan gambaran tentang kewajiban suami istri yang wajib dijalani, seperti saling mencintai dan membahagiakan, setia, membangun keluarga yang harmonis, menghormati satu sama lain, dan memberikan bantuan lahir bathin antar pasangan. 
c. Istri memiliki kewajiban untuk mengatur seluruh kebutuhan dalam rumah tangga dengan sebaik-baiknya. Pada kategori ini diharapkan terdapat adegan film yang memberikan gambaran tentang kewajiban istri untuk mengatur seluruh kebutuhan rumah tangga dengan sebaik-baiknya.

d. Menjaga hubungan pernikahan agar terhindar dari sebuah perceraian. Pada kategori ini diharapkan terdapat adegan film yang memberikan gambaran tentang pasangan suami istri yang mampu menjaga hubungan pernikahan mereka untuk terhindar dari perceraian.

\section{Mitos Pernikahan (Perkawinan)}

Sebuah artikel tentang mitos perkawinan yang dimuat Tabloid Nova tahun 2015 (www.intisari.grid.id) menerangkan beberapa mitos tentang perkawinan, yakni sebagai berikut:

a. Perkawinan lebih menguntungkan pria daripada wanita. Kenyataannya bahwa pria dan wanita memperoleh keuntungan yang sama dari sebuah perkawinan walaupun dengan cara yang berbeda

b. Kehadiran anak meningkatkan kebahagiaan suami istri. Hubungan jadi lebih dekat. Kenyataannya tidak sedikit kelahiran anak pertama merenggangkan hubungan suami istri, serta menimbulkan stress karena sibuknya sang istri mengurus bayi sementara suami merasa tidak diperhatikan.

c. Cinta yang romantik dan keberuntungan merupakan kunci suksesnya sebuah perkawinan. Kenyataannya selain cinta yang romantic dan keberuntungan, suksesnya perkawinan karena hasil kerja keras, dedikasi serta komitmen dan pasangan merupakan sahabat dalam suka dan duka.

d. Semakin berpendidikan seorang wanita, semakin kecil kemungkinan baginya untuk menikah. Kenyataannya banyak wanita berpendidikan tinggi yang menikah

e. Pasangan yang hidup bersama sebelum menikah, pernikahannya bakal lebih langgeng daripada pasangan yang menikah tanpa melakukan hidup bersama terlebih dahulu. Faktanya angka perceraian justru lebih tinggi pada pasangan yang hidup bersama sebelum menikah dibandingkan pada pasangan menikah tetapi tidak hidup bersama setelah menikah.

f. Risiko mendapat kekerasan di dalam rumah tangga lebih tinggi pada wanita menikah dibandingkan dibandingkan dengan wanita tidak menikah.

\section{Semiotika Roland Barthes}

Roland Barthes merupakan tokoh semiotika yang melanjutkan pemikiran Saussure. Menurut Barthes, semiotik merupakan salah satu bagian dari ilmu pengetahuan yang mempelajari tentang bagaimana manusia memaknai sesuatu yang ada di sekitarnya. Makna didapatkan dari tanda yang membawa pesan tersirat, dalam pandangan Saussure menekankan penandaan hanya dalam tataran denotasi dan konotasi. Kemudian Barthes melalui pemikirannya penandaan itu disempurnakan dari semiologi Saussure dengan sistem penandaan konotatif dan mitos.

Pada analisis Barthes terdapat tiga hal inti yang diperhatikan, yaitu makna Denotatif, Konotatif, dan Mitos. Pada makna tingkat pertama disebut dengan 
Denotatif, dan tingkat pemaknaan kedua disebut dengan Konotatif. Denotatif akan mengungkapkan makna yang terlihat jelas oleh mata, artinya denotatif merupakan makna yang sebenarnya. Sedangkan Konotatif mengungkapkan makna yang terkandung dalam tanda-tanda.

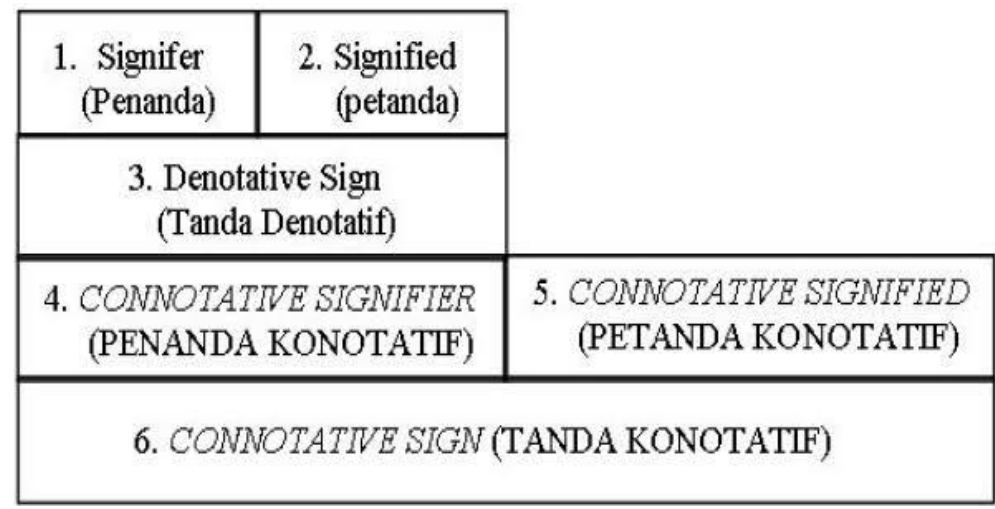

Gambar 2.1. Teori Semiotika Roland Barthes

Berbeda dengan mitos, yang ada dan berkembang dalam benak masyarakat karena adanya pengaruh sosial atau budaya masyarakat itu sendiri akan sesuatu, dengan cara memperhatikan dan memaknai korelasi antara apa yang terlihat secara nyata (denotatif) dengan tanda apa yang tersirat dari hal tersebut (konotasi) (Putu Krisdiana Nara Kusuma dan Iis Kurnia Nurhayati, 2017).

Menurut gambaran Barthes seperti terlihat di atas menunjukkan bahwa tanda denotatif (3) terdiri atas: penanda (1) dan petanda (2). Akan tetapi, pada saat bersamaan, tanda denotatif adalah juga penanda konotatif (4) Dengan kata lain, kata Cobley \& Jansz, hal tersebut merupakan unsur material hanya jika kita mengenal tanda "singa", barulah konotasi seperti harga diri, kegarangan, dan keberanian menjadi mungkin. Dalam pandangannya, tanda konotatif tidak sekedar memiliki makna tambahan tetapi juga mempunyai kedua bagian tanda denotatif yang melandasi keberadaannya. Inilah sumbangan terbesar Barthes bagi penyempurnaan semiologi Saussure yang berhenti pada penandaan dalam tataran denotatif.

\section{METODOLOGI PENELITIAN}

Dalam penelitian ini peneliti menggunakan jenis penelitian kualitatif dengan sifat deskriptif. Deskriptif merupakan salah satu sifat penelitian kualitatif yang ditujukan untuk mendeskripsikan fenomena-fenomena yang ada, baik fenomena alamiah maupun fenomena yang dibuat oleh seseorang. Sehingga penelitian deskriptif kualitatif dalam penelitian ini bertujuan untuk menjelaskan data-data secara sistematis, rinci, lengkap dan mendalam untuk menjawab masalah yang akan diteliti dalam penelitian ini.

Metode analisis yang digunakan ialah semiotika model Semiotik milik Roland dengan menganalisis tiga tanda yaitu visual, verbal, serta audio, yang kemudian nantinya akan dihubungkan sehingga dapat menarik makna denotatif dan 
konotatifnya yang kemudian akan menghasilkan mitos. Dalam penelitian ini yang menjadi subjek penelitian yakni film Wedding Agreement. Objek dalam penelitian ini yaitu isi dari film yakni tentang pesan moral pernikahan yang terkandung dalam film. Unit analisis dalam penelitian ini meliputi tanda-tanda verbal dan tanda-tanda visual (non verbal) yang terdapat dalam setiap scene dengan menggunakan teknik semiotika. Susunan urutan dari berbagai peristiwa yang terjadi di dalam film. Berbagai shot yang saling berhubungan dan berurutan, yang dikembangkan dengan memberikan subyek di dalamnya.

Dalam mengolah dan menganalisis data peneliti melakukan tahapan yaitu menonton dan mengamati segala adegan yang ada dalam film tersebut, serta berbagai percakapan yang terjadi. Mereduksi data yaitu memilah-milah setiap adegan dalam film yang termasuk ke dalam kategori pesan moral pernikahan. Kemudian menganalisis data berdasarkan analisis semiotika Roland Barthes berupa Denotatif, Konotatif, dan Mitos yang terdapat didalam film Wedding Agreement.

\section{HASIL DAN PEMBAHASAN}

Film Wedding Agreement ini sekilas menceritakan tentang pernikahan antara Biyan dengan Btari yang dijodohkan oleh orangtua. Biyan terpaksa meninggalkan pacarnya yang bernama Sarah untuk menikahi Btari karena keinginan orangtuanya. Biyan pun berjanji kepada Sarah hanya satu tahun saja dia menikahi Biyan untuk Kembali lagi kepada Sarah. Hasil penelitian menunjukkan bahwa di dalam film Wedding Agreement terdapat beberapa scene yang merepresentasikan moral pernikahan. Di antaranya sebagai berikut:

Pada menit ke 12:58-15:50 terlihat adegan dimana tokoh utamanya yakni Biyan dan Btari datang menghadiri ulangtahun Ayah dari Biyan. Untuk menunjukkan keharmonisan di hadapan orangtuanya, mereka bergandengan tangan seperti terlihat pada cuplikan adegan berikut ini:

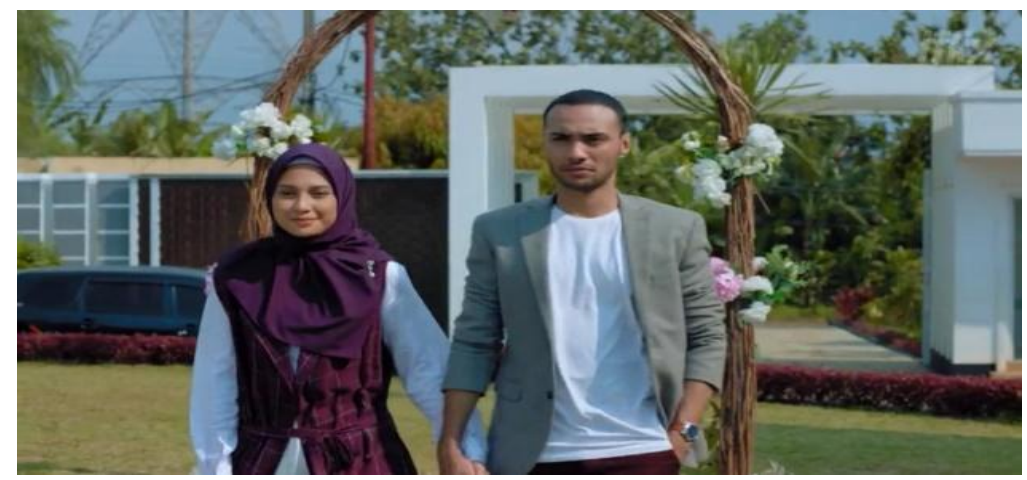

Gambar 1 : Biyan dan Btari berpegangan tangan saat menghadiri ulangtahun Ayah Biyan

Secara denotasi (kasat mata) sebagai sepasang suami istri, mereka berpegangan tangan, wajah Btari terlihat senyum Bahagia, namun tidak halnya Biyan. Mimik mukanya dingin dan tidak senyum. Adegan ini secara konotasi 
menunjukkkan bahwa harmonisasi yang mereka ciptakan tersebut terlihat dipaksakan dan tidak menyenangkan bagi kedua belah pihak, terutama bagi Biyan. Hanya saja untuk menghormati kedua orangtuanya, Biyan mau melakukannya untuk memperlihatkan bahwa kehidupan rumah tangganya bersama Btari harmonis. Upaya Biyan dan Btari yang "terpaksa" tersebut sebenarnya ingin menegaskan bahwa di dalam kehidupan rumah tangga sesungguhnya pasangan suami istri memang memiliki kewajiban untuk membangu sebuah keluarga yang harmonis, saling mencintai dan membahagiakan.

Berikutnya pada menit ke 05:37 - 07:11 terlihat beberapa cuplikan adegan yang menunjukkan bagian lain dari moral pernikahan yakni istri memiliki kewajiban untuk mengatur seluruh kebutuhan dalam rumah tangga dengan sebaik-baiknya. Cuplikan adegan tersebut memperlihatkan bagaimana Btari berupaya untuk memposisikan diri sebagai istri yang mencoba melaksanakan kewajibannya mengurusi kebutuhan suami dan rumah tangga.

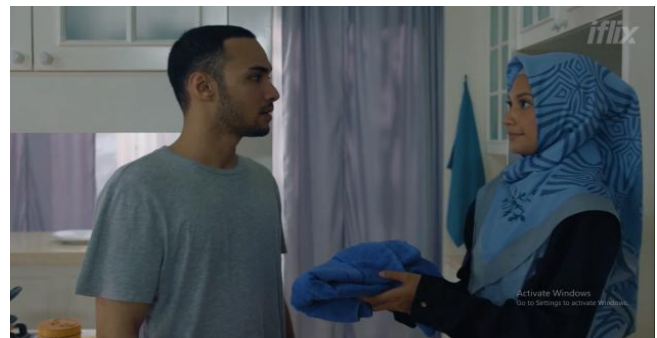

Gambar 2: Btari melayani Biyan yang akan mandi dengan memberikan handuknya

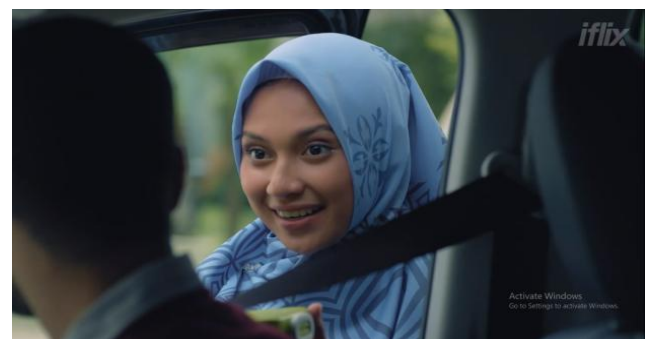

Gambar 3: Btari membawakan bekal makan untuk Biyan

Pada secene tersebut secara denotasi diawali dengan adegan Btari selalu mempersiapkan segala kebutuhan Byan, mulai mempersiapkan sarapan dan makan malam Byan, mencuci pakaian Byan. Btari tetap menjalankan perannya sebagai istri, meski Byan selalu menolak semua hal yang dilakukannya. Kemudian Btari pun memberikan handuk yang ia cuci saat Biyan akan mandi dan membawakan bekal makan untuk Biyan. Secara konotasi hal itu menunjukkan kesungguhan Btari dalam menjalankan perannya sebagai seorang istri.

Lalu pada menit ke 38:35-42:34 terlihat ada beberapa scene yang memperlihatkan moral pernikahan lainnya yakni menjalani kewajiban pernikahan untuk saling mencintai dan membahagiakan, setia, membangun keluarga yang harmonis, menghormati satu sama lain, dan memberi bantuan lahir bathin kepada pasangan. Secara denotasi terlihat pada beberapa cuplikan adegan berikut ini: 


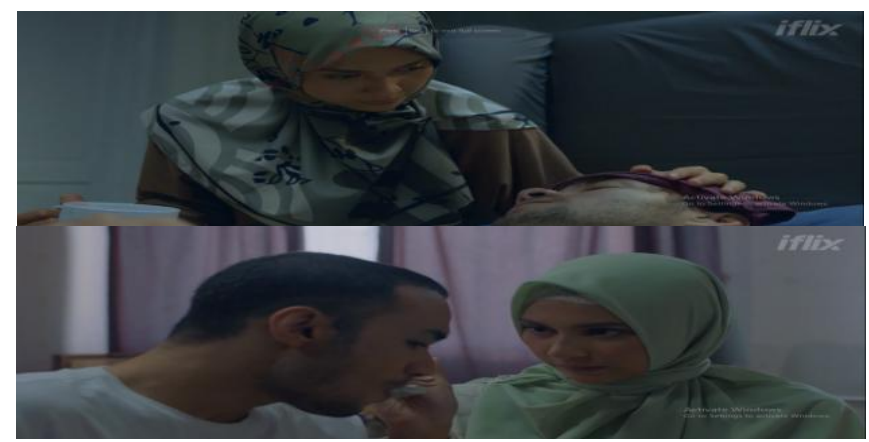

Gambar 4: Btari merawat Biyan yang sedang sakit

Secara denotasi Btari terlihat selalu ada di samping Biyan saat Biyan sakit. Meski di dalam surat perjanjian pernikahan telah disebutkan, kalau kedua pasangan antara Byan dan Btari tidak boleh mengurus keperluan satu sama lain. Serta, tidak diwajibkan untuk menjalankan kewajibannya sebagai suami atau istri. Meskipun begitu Btari tetap mengurusi Byan yang sedang sakit dan memperlakukan Biyan sebagaimana istri memperlakukan suaminya. Btari mengompres serta menyuapi Biyan. Hal itu ia lakukan untuk menunjukkan kesetiaan dan rasa cintanya kepada Biyan. Perasaan tersebut juga secara konotasi terlihat dari komunikasi nonverbal melalui sentuhan saat mengompres kening Biyan dan tatapan penuh rasa kasih dan saying saat menyuapi Biyan.

Pada menit ke Menit ke 20:34 - 21:45 tergambarkan moral pernikahan berupa menjaga hubungan pernikahan agar terhindar dari sebuah perceraian. Secara denotasi hal ini terpapar dalam percakapan antara Biyan dan Btari berikut ini:

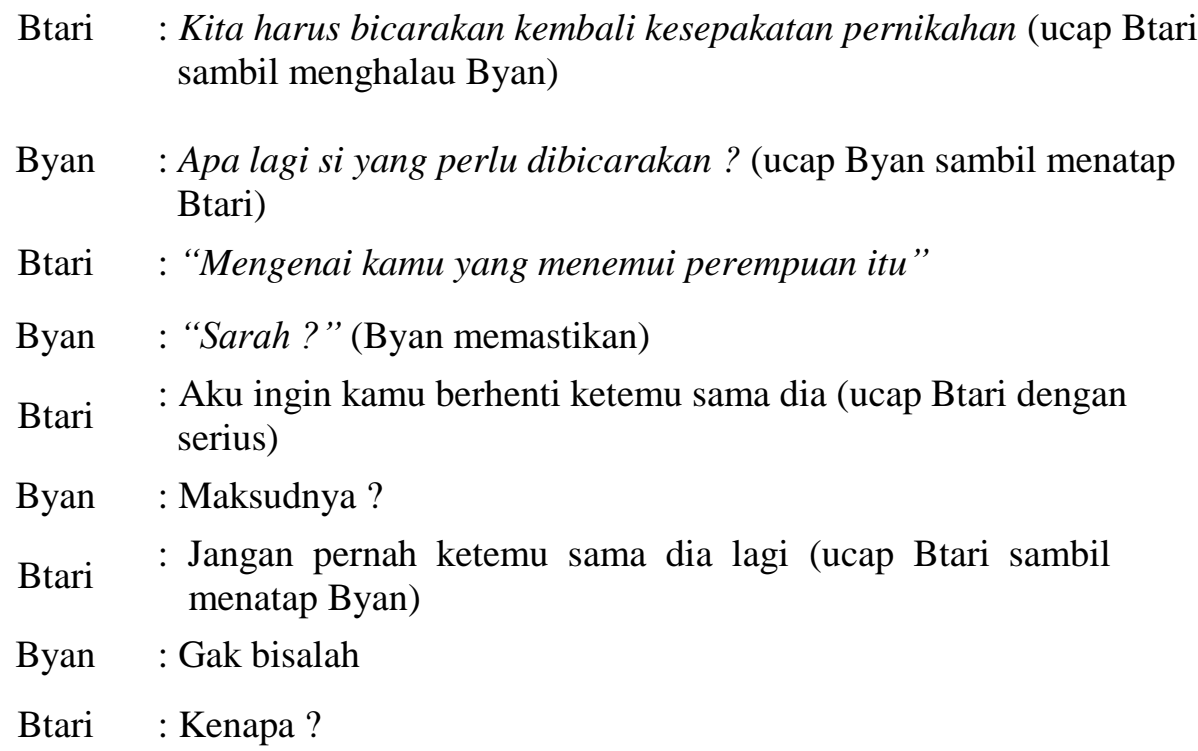


Byan : Kenapa harus ? (ucap Byan dengan nada remeh) Btari : Aku gak mau ada anggota keluarga yang tahu kalian jalan

Byan : Nggak akan, aku selama ini selalu hati-hati kok (kilah Byan)

: Mas, aku tahu kita menikah ini karena dijodohkan. Kamu

Btari boleh terpaksa untuk menjalani ini, tetapi aku enggak! (ucap Btari dengan mata berkaca-kaca). Aku menjalani pernikahan ini dengan sungguh-sungguh, mas. Karena menikah itu adalah ibadah (jelas Btari).

Dari percakapan tersebut, upaya untuk mempertahankan hubungan pernikahan agar terhindar dari perceraian terlihat dari ungkapan Btari yang mengaku jika ia tidak terpaksa menjalankan pernikahan, malah sungguh-sungguh dengan niat ibadah (denotasi). Ungkapan verbal tersebut dikuatkan oleh non verbal Btari (konotasi) ketika berbicara dengan Biyan, di antaranya mata berkaca-kaca dan sikap menghalau Biyan ketika Biyan menghindari percakapan. Non verbal tersebut mengungkapkan isi hati terdalam Btari yang sungguh-sungguh tidak ingin terjadi perpisahan.

Moral menjaga hubungan pernikahan agar terhindar dari sebuah perceraian pun terlihat pada adegan di menit

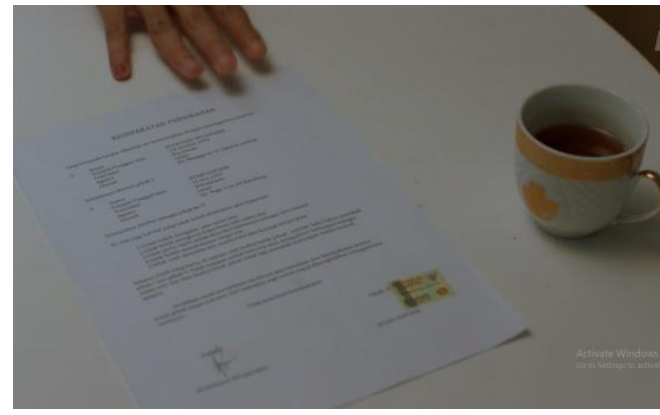

Gambar 5: Biyan menyodorkan surat perjanjian

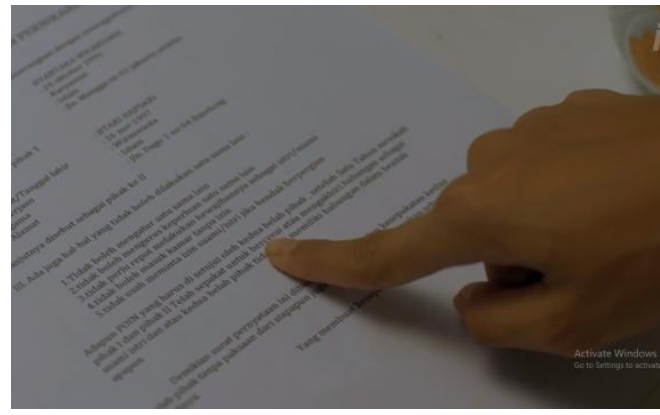

Gambar 6: Btari mempertanyakan poin perceraian

Secara denotasi adegan tersebut mengambarkan saat Byan monyodorkan surat perjanjian pernikahan kepada Btari, dan meminta untuk menyetujuinya. Btari merasa bingung dengan surat perjanjian yang dimaksudkan oleh Byan, ditambah usai membaca Btari merasa bingung dengan salah satu poin yang menyebutkan mereka akan bercerai usai satu tahun menikah. Hal tersebut tergambarkan dalam gambar 3. Kemudian Btari menanyakan apa yang dimaksud Byan terhadap surat perjanjian tersebut. Dalam penjelasannya Byan menyebutkan alasan ia menerima pernikahan ini, karena hanya ingin mengikuti kemauan dari ibunya yang sedang sakit bukan karena tertarik dengan Btari ataupun mencintai Btari. 
Selain itu, dalam penjelasannya Byan mengatakan bahwa dirinya telah memiliki tunangan bernama Sarah dan memiliki rencana untuk menikah karena Byan sangat mencintai Sarah. Setelah Byan menjelaskan semuanya, Byan mengatakan bila Btari tidak menyetujui surat perjanjian tersebut ia bisa langsung mengajukan perceraian. Lalu, Byan langsung pergi begitu saja meninggalkan Btari yang hanya terdiam. Adengan ini dilengkapi dengan percakapan, sebagai berikut :

Btari : "Ini maksudnya apa?”

(ucap Btari sambil menunjuk poin perceraian dalam surat perjanjian)

: “Jelaskan, dari awal aku itu berencana pisah sama kamu setelah satu tahun menikah. Mungkin kamu belum tahu, aku sudah tunangan dan

Byan aku cinta banget sama tunangan aku, Sarah. Aku terpaksa menikah dengan kamu tapi bukan untuk waktu yang lama” (ucap Byan dengan nada tegas)

: "Astafirullahalazim, jadi kamu bermaksud untuk mempermaikan Btari pernikahan kita? Kaтu nggak memikirkan keluarga kamu ? Кати nggak mikirin keluarga aku? Aku menikah bukan untuk ini" (Dengan suara bergetar dan emosi Btari menunjuk surat tersebut)

Kalimat "Astafirullahalazim, jadi kamu bermaksud untuk mempermaikan pernikahan kita? Kaтu nggak memikirkan keluarga kaтu ? Kaтu nggak mikirin keluarga aku? Aku menikah bukan untuk ini" yang diucapkan Btari secara bergetar dan emosi secara konotasi bermakna bahwa Btari berkeinginan untuk menikah sekali seumur hidupnya. Dia ingin mempertahankan rumah tangganya dan tidak ingin bercerai, karena hal itu sama saja dengan mempermainkan kesakralan pernikahan. Menikah bukan hanya sekedar tentang cinta. Tapi memerlukan komitmen atas pilihan, dan menerima semua kosekuensi yang akan diterima setelah pernikahan tersebut terjadi. Secara Mitos seseorang yang pernah mengalami perceraian akan dipandang buruk oleh masyarakat karena dianggap tidak dapat mempertahankan pernikahannya.

Representasi moral mempertahankan hubungan pernikahan pun terlihat pada secene ke 01:16:09 melalui cuplikan adegan-adegan berikut ini:

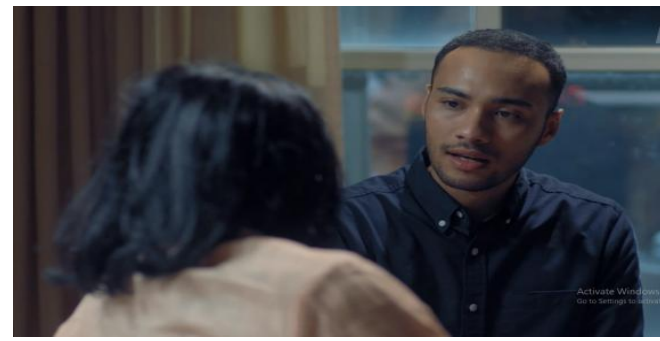

Gambar 7 Biyan mengakhiri hubungan dengan Sarah

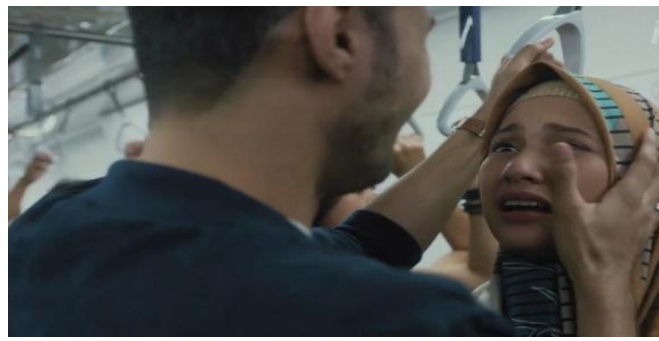

Gambar 8 Biyan mencari Btari 
Adegan ini berada dibagian akhir film. Secara denotasi Byan menemui Sarahdan mengatakan kepada Sarah jika ia ingin mengakhir hubungan di antara mereka. Byan menyampaikan alasannya bahwa ia telah merasa nyaman dan terbiasa hidup dengan Btari. Tentu saja Sarah sangat marah dan kecewa usai mendengarkan penjelasan dari Byan. Padahal di awal pernikahan Byan yang meminta Sarah untuk menunggunya selama satu tahun hingga pernikahannya dengan Btari usai. Byan tidak peduli dengan kemarahan Sarah. Dia memilih segera meninggalkan Sarah yang terus menerus memanggil namanya. Kemudian Byan segera mencari Btari yang pergi dari rumah. Setelah mendengar kabar kalau Btari pergi ke pengadilan, secepat mungkin Byan langsung mengejar Btari menuju Kantor Pengadilan Agama. Di tengah perjalanan Byan memutuskan untuk menggunakan MRT karena jalan yang dilalui saat itu sangat macet. Ternyata saat di dalam MRT tak sengaja Byan bertemu dengan Btari. Perasaan lega dan haru terlihat dalam raut wajah Byan, ia langsung menghampiri Btari dan memeluknya. Selanjutnya Byan mengatakan bahwa ia memilih Btari untuk tetap menjadi istrinya dan melupakan isi surat perjanjian tersebut.

\section{PEMBAHASAN}

Untuk memudahkan peneliti dalam menganalisis makna pesan moral pernikahan yang terkandung dalam film, peneliti membaginya ke dalam empat kategori tentang moral pernikahan yang terdapat di dalam adegan-adegan film Wedding Agreement, di antaranya adalah :

\section{Kesiapan Mental Pasangan Kehidupan Dalam Menjalani Pernikahan.}

Pada poin ini tidak begitu tampak dalam adegan film Wedding Agreement, hal tersebut disebabkan kedua pasangan yaitu Byan dan Btari menikah karena dijodohkan. Sehingga adegan di dalam film tidak tergambarkan bahwa mereka secara mental siap menjalani kehidupan pernikahan, mereka hanya sebatas mengetahui hak dan kewajiban seorang suami istri. Selain itu, alasan Byan yang menerima pernikahan ini hanya sebatas menghormati keinginan ibunya yang sedang sakit bukan karena ia memiliki perasaan dengan Btari. Padahal kesiapan mental dalam menghadapi pernikahan sangat penting, karena jika tidak ada kesiapan secara mental dapat menimbulkan resiko yang akan terjadi seperti konflik atau yang paling berat yaitu perceraian. Seorang pasangan harus dapat memahami satu sama lain, adanya keinginan untuk berubah, dan menerima seluruh kekurangan dan kelebihan yang dimiliki pasangan.

\section{Menjalani Kewajiban Pernikahan Untuk Saling Mencintai dan Membahagiakan, Setia, Membangun Keluarga Yang Harmonis, Menghormati Satu Sama Lain, dan Memberi Bantuan Lahir Bathin Kepada Pasangan.}

Sebagaimana termaktub dalam Undang-Undang Perkawinan tahun 1974 sejatinya pernikahan itu harus dijalani dengan sungguh-sungguh. Harus ada Kerjasama yang baik antara suami dan istri untuk saling mencintai dan membahagiakan, saling setia, saling memberi bantuan lahir bathin kepada pasangan memberi untuk membangun harmonisasi keluarga. Dalam film ini tidak tergambar 
gambaran utuh bagaimana seharusnya peran suami dalam keluarga. Hal ini dikarenakan sosok suami dalam film ini merasa terpaksa menjalani pernihakan. Usaha keras hanya terlihat dari sosok istri yang tidak lelah menjalakan perannya sebagai seorang istri. Terlebih ketika menghadapi upaya suami untuk berpisah darinya. Padahal menurut perspektif islam, suami memiliki kewajiban untuk memberi nafkah lahir bathin kepada istri, sebagaimana tercantum juga dalam bergaullah dengan mereka (istri) secara patut. Kemudian bila kamu tidak menyukai mereka, (maka bersabarlah) karena mungkin kamu tidak menyukai sesuatu, padahal Allah menjadikan padanya kebaikan yang banyak." (An Nisa:19).

Pesan moral yang ingin disampaikan dalam beberapa adegan "perjuangan" sang istri ini adalah seorang istri tidak boleh pasrah begitu saja. Namun dia tetap harus berikhtiar untuk menciptakan kebahagiaan di dalam sebuah rumah tangga. Hal ini sekaligus mematahkan mitos yang menyebutkan bahwa cinta yang romantik dan keberuntungan merupakan kunci suksesnya sebuah perkawinan. Kenyataannya selain cinta yang romantic dan keberuntungan, suksesnya perkawinan karena hasil kerja keras, dedikasi serta komitmen dan pasangan merupakan sahabat dalam suka dan duka.

\section{Istri Memiliki Kewajiban Untuk Mengatur Seluruh Kebutuhan Dalam Rumah Tangga Dengan Sebaik-Baiknya.}

Dalam film ini sosok Btari digambarkan sebagai istri yang mampu mengatur atau mengurus seluruh kebutuhan rumah tangganya, hal tersebut terlihat dalam beberapa adegan yang ada dalam adegan. Dalam film ini diceritakan bagaimana sosok istri (Btari) yang tetap melayani suami dengan penuh cinta kasih dan tulus. Bagaiaman ia merawat suaminya yang sakit, melayani kebutuhan suaminya hingga menjadi seorang istri yang setia menunggu kepulangan suami di rumah. Pesan moralnya adalah sekalipun suami tidak bersikap baik, seorang istri tetap harus menjalankan kewajibannya. Hal itu sekaligus juga merepresentasikan kewajiban seorang istri dalam perspektif islam, yakni Hormat dan patuh pada suami dalam batas-batas yang ditentukan oleh norma dan Susila dan selalu bersikap manis. Begitu pula dalam Undang-Undang perkawaninan bahwa istri wajib mengatur urusan rumah tangga sebaik-baiknya.

\section{Menjaga Hubungan Pernikahan Agar Terhindar Dari Sebuah Perceraian. Pada Kategori Ini Diharapkan Terdapat Adegan Film Yang Memberikan Gambaran Tentang Pasangan Suami Istri Yang Mampu Menjaga Hubungan Pernikahan Mereka Untuk Terhindar Dari Perceraian.}

Kategori ini tergambar pada beberapa ucapan misalnya ketika sang istri (Btari) mengatakan bahwa ia tidak main-main dengan pernikahan, kedua adegan tersebut memiliki makna bahwa pernikahan merupakan hubungan yang wajib untuk dijaga dan terhindar dari sebuah perceraian, karena pernikahan bukan hanya menyangkut dua pasangan saja, tetapi keberadaan keluarga juga yang harus dipikirkan setiap melakukan hal apapun termasuk untuk bercerai. Pernikahan wajib dijalani dengan sebaik mungkin, karena salah suatu keharusan dan sebagian dari ibadah yang dijalanin oleh setiap manusia. Selain itu, setiap pasangan diwajibkan 
untuk menjaga hubungan mereka agar terhindar dari perceraian. Sebab, keputusan untuk bercerai harus dipikirkan baik-baik. Hal ini sebagaimana diisyaratkan dalam Undang-Undang Nomor 1 Tahun 1974 tentang perkawinan dan Kompelasi Hukum Islam Tahun 1991 mengandung 7 (tujuh) asas atau kaidah hukum, bahwa salah satu azas yang harus ditaati oleh pasangan suami istri adalah asas mempersulit perceraian.

Selain itu peneliti menilai film Wedding Agreement tidak hanya membahas tentang pesan moral pernikahan saja, tetapi terdapat disikap moral lainnya yang dapat diambil dan dijadikan pembelajaran oleh orang yang menonton film ini. Misal, dalam nilai kejujuran yang ada dalam adegan saat Btari selalu mengatakan bahwa ia tidak pernah berpura-pura menjalani pernikahannya, ia selalu sungguh-sungguh melakukannya.

\section{SIMPULAN}

Berdasarkan analisi yang telah peneliti lakukan dengan data-data yang diperoleh dalam proses penelitian dapat disimpulkan bahwa beberapa adegan dalam film Wedding Agreement menggambarkan pesan moral pernikahan. Representasi moral yang cukup banyak adalah moral mempertahankan hubungan pernikahan agar terhindar dari perceraian.

Tetapi pada dalam pernikahan yang dijalani adanya ketidaksiapan mental dari Byan dan Btari dalam menjalani pernikahan, karena perjodohan yang mereka jalani. Sehingga, keduanya belum dapat memahami perasaan satu sama lain dan memahami makna tentang pernikahan khususnya untuk tokoh Byan. Dari banyaknya tokoh yang ada dalam film ini, nilai-nilai moral banyak dapat ditemui dalam sosok Btari yang cukup religius. Btari digambarkan sebagai sosok yang sabar, menjalankan tugasnya sebagai istri yang baik, mendukung suami dalam keadaan apapun, dan tidak pernah menyerah untuk tetap mempertahankan pernikahannya. Selain itu, film ini tidak hanya sarat dengan pesan moral pernikahan saja. Tetapi di dalam film ini kita juga banyak pesan moral tentang kehidupan sehari-hari dan nilainilai agama yang dapat dijadikan pembelajaran orang yang menontonnya. Misalnya, nilai kejujuran, keberanian, bertanggung jawab, dan kemandirian.

\section{DAFTAR PUSTAKA}

Atabik, Ahmad dan Khoridatul Mudhiah. (2014). Pernikahan dan Hikmahnya Perspektif Hukum Islam. Yudisia: Jurnal Pemikiran Hukum dan Hukum Islam 5(2):286-316

Analisis Semiotika Roland Barthes Pada Ritual Otonan di Bali. (2013). Arti Penting Pernikahan. Jurnal Al-Hikamh Vol. XIV No. 2, 257.

Bertens, K. (2011). Etika. Jakarta: PT Gramedia Pustaka Utama. 
Detik.com, Hampir Setengah Juta Orang Bercerai di Indonesia Sepanjang Tahun 2018. Diakses pada 20 Desember 2019. https://news.detik.com/berita/d4495627/hampir-setengah-juta-orang-bercerai-di-indonesia-sepanjang-2018.

Hadiwardoyo, A. P. (1994). Moral dan Masalahnya. Yogyakarta: Kanisius.

Hafiza, Idayu. (2018). Konseling Pranikah Dalam Upaya Meningkatkan Kesiapan Mental Menuju Keluarga Sakinah Pada Mahasiswi Psikologi Semester VIII Tahun Ajaran 2017/20118, UIN Sunan Ampel Surabaya. Skripsi, Program Studi Bimbingan Konseling Islam Jurusan Dakwah Fakultas Dakwah Dan Komunikasi Universitas Islam Negeri Sunan Ampel Surabaya. 2018.

https://www.idntimes.com/hype/entertainment/stella/infografis-minat-penontonterhadap-film-indonesia/full.

http://pm.unida.gontor.ac.id/2019/09/11/hak-dan-kewajiban-suami-istri-dalam-duaperspektif-yaitu-syariat-islam-dan-menurut-uu-perkawinan/

http://www.intisari.grid.id.

IDN Times. Infografis Minat Penonton Terhadap Film Indonesia, 2019.

Kompasiana, Memaknai Ketulusan Cinta Sebuah Pernikahan dalam Wedding Agreement. Diakses pada 13 Januari 2019 pukul 23.29, https://www.kompasiana.com/saepullahabuzaza/5d501b180d823074733dffb 2/memaknai-ketulusan-cinta-sebuah-pernikahan-dalam-weddingagreement?page $=$ all

Matondang, A. (2014). Faktor-faktor yang Mengakibatkan Perceraian dalam Perkawinan. JPPUMA: Jurnal Ilmu Pemerintahan dan Sosial Politik UMA (Journal of Governance and Political Social UMA), 2(2), 141-150. doi:https://doi.org/10.31289/jppuma.v2i2.919.

Nurhayati, P. K. (2017). Analisis Semiotika Roland Barthes Pada Ritual Otonan di Bali. Jurnal Manajemen Komunikasi, Vol. 1 No. 2.

Tantu, Asbar. (2013). Arti Pentingnya Pernikahan, Al-Hikmah Journal for Religious Studies 14 (2), 199-208.

Tugiman, H. (2012). Etika Rambu-Rambu Kehidupan. Yogyakarta: Kanisius. 